\title{
ARPP-21, A Cyclic AMP-Regulated Phosphoprotein Enriched in Dopamine-Innervated Brain Regions. II. Molecular Cloning and Nucleotide Sequence
}

\author{
Tatsuya Kurihara, ${ }^{1,2}$ Michelle E. Ehrlich, ${ }^{1}$ Junjiro Horiuchi, ${ }^{1}$ Takaaki Nasu, ${ }^{2}$ and Paul Greengard ${ }^{1}$ \\ 'Laboratory of Molecular and Cellular Neuroscience, The Rockefeller University, New York, New York 10021, and \\ ¿Laboratory of Molecular Biology, Suntory Institute for Biomedical Research, Mishimagun, Osaka 618, Japan
}

\begin{abstract}
A cDNA clone for the mRNA of bovine ARPP-21 (CAMPregulated phosphoprotein, $M_{r}=21,000$ as determined by SDS-PAGE) was isolated from a modified Okayama-Berg plasmid library. Transformed Escherlchla coll colonles were screened by in situ colony hybridization with 2 different oligonucleotide probes derived from the amino acid sequence of the bovine protein. Sequence analysis of the longest CDNA clone, pTKAI [2407 nucleotides plus a poly(A) tail], revealed a 267-nucleotide-long coding region in agreement with the bovine ARPP-21 amino acid sequence (Williams et al., 1989). Southern blot analysis of total bovine genomic DNA raised the possibility that there may be 2 genes coding for ARPP. 21. Northern blot analysis of total cellular RNA from bovine caudate nucleus and other brain regions demonstrated the existence of 2 major mRNA species, 2.5 and $1.0 \mathrm{~kb}$ in length, probably derived from use of alternate polyadenylation sites. There was a differential expression of these 2 mRNAs within the brain. Both ARPP-21 mRNAs were most abundant in the caudate nucleus, where the concentration of the protein is highly enriched.
\end{abstract}

Studies of the regional distribution of substrates for cAMPdependent protein kinase in mammalian brain revealed that 7 of these proteins are highly enriched in the basal ganglia (Walaas et al., 1983). ARPP-21 (cAMP-regulated phosphoprotein, $M_{r}=21,000$ as determined by SDS-PAGE), one of these proteins, has been purified to homogeneity from bovine caudate nucleus, biochemically characterized (Hemmings and Greengard, 1989) and its amino acid sequence determined (Williams et al., 1989). In this paper, we describe the isolation and characterization of a cDNA clone for bovine ARPP-21 identified by use of an in situ colony hybridization method with oligonucleotide probes. We have used this clone to study the regional distribution of ARPP-21 mRNA in bovine brain and to carry out a genomic analysis of this protein. The availability of cDNA probes will greatly facilitate the study of the phosphoprotcins enriched in the medium spiny neurons of the caudate nucleus, including the regulation of their coordinated expression in this

\footnotetext{
Received Dec. 17, 1988; revised Apr. 4, 1989; accepted Apr. 10, 1989.

This work was supported by USPHS grants MH 40899 and NS 22789 and an NIMH Physician Scientist Award to M.E.E. We thank Dr. Jean-Antoine Girault (The Rockefeller University) for carrying out the bovine brain microdissection and for stimulating discussion. We thank Dr. Teruhisa Noguchi (Suntory Institute for Biomedical Research) for his great interest in and support of this study.

Correspondence should be addressed to Paul Greengard, Box 296, The Rockefeller University, 1230 York Avenue, New York, NY 10021.

Copyright $(1989$ Society for Neuroscience $0270-6474 / 89 / 103638-07 \$ 02.00 / 0$
}

specific type of neuron. This information should increase the understanding of the role of these proteins in the functions of the medium spiny neurons.

\section{Materials and Methods}

Bacterial strains and plasmids. Escherichia coli $\mathrm{K}-12$ strains used were WA802 [metBl, lacY or lac3, galK2, galT22, $\lambda$, supE44, end $A, s b c B$, hsd3] (Wood, 1966; Nelson et al., 1981), JM103 [ $\Delta$ (lac-pro), supE, thi, strA, sbcBl5, endA, hspR4, F'traD36, proAB, lacI' $Z \Delta M l 5]$ (Messing et al., 1983) and JM109 [recAl, endAl, gyrA96, thi, hsdRl7, supE44, $\lambda$-, $\Lambda$ (lac-proAB), F'traD36, pro $A B$, lac $I^{q} Z \Delta M l 5$ ] (Yanish-Perron et al., 1985). Plasmids included pSV7186 (Pharmacia), pGEM4 (Promega Biotec), and pTK501 (Kurihara et al., 1988). E. coli strains harboring these plasmids were grown in LB medium containing $50 \mu \mathrm{g} / \mathrm{ml}$ ampicillin.

Preparation of bovine caudate RNA. Total RNA $(2.8 \mathrm{mg})$ was isolated from calf caudate nuclei $(6 \mathrm{gm})$ by extraction with guanidine isothiocyanate followed by sedimentation through cesium chloride (Chirgwin et al., 1979). Poly (A)+ RNA (200 $\mu \mathrm{g})$ was enriched by a single cycle of oligo(dT)-cellulose (Type 3, Collaborative Research) chromatography (Aviv and Leder, 1972; Zelenka and Piatigorsky, 1974).

Preparation of oligonucleotide hybridization probes. Two oligonucleotide probes, oligo TK3 and oligo TK4 (Fig. 1), were prepared with the DNA Synthesizer 308A (Applied Biosystems) and purified by Sephadex G-100 (Pharmacia) column chromatography in TEAB buffer ( 10 $\mathrm{mM}$ triethylamine bicarbonate, $\mathrm{pH} 8.5$ ). The degeneracy of oligo TK3 was 32, and that of oligo TK4 was 1152 . Oligonucleotides were labeled at the $5^{\prime}$ end with $\left[\gamma-{ }^{32} \mathrm{P}\right]$ ATP using T4 polynucleotide kinase, followed by purification using Sephadex G-50 (Pharmacia) column chromatography. The specific activities of these probes were $>10^{8} \mathrm{cpm} / \mu \mathrm{g}$ DNA.

Colony hybridization. A bovine caudate nucleus cDNA library (Kurihara et al., 1988) was screened at a density of 2200 and 6600 colonies/ $82 \mathrm{~mm}$ Petri dish. The DNA from lysed bacteria was transferred to nitrocellulose filters as described by Maniatis et al. (1982) and Grunstein and Hogness (1975) with minor modifications (Kurihara et al., 1988). The conditions for probing the filters have been previously described (Kurihara et al., 1988).

Sequencing of $c D N A$ fragments. The entire cDNA region of $\mathrm{pTKAl}$ was inserted into the Hinc II site of M13mp19 in both orientations. Sequential DNA deletions were obtained with T4 DNA polymerase (Dale et al., 1985), and sequences were determined by the dideoxy chain termination method (Sanger et al., 1977; Messing, 1983). Sequencing was also performed using restriction fragments of pTKAl inserted into appropriate sites in M13mp18 and mp19 phage (Pharmacia).

Preparation of antisense RNA probes. ARPP-21 antisense RNA probes were used for Northern and Southern blot hybridizations. The antisense probes were synthesized with SP6-polymerase in pGEM4 (Promega Biotec) according to Melton et al. (1984). Plasmids included pTKAlG4.2, which contained the $0.65 \mathrm{~kb}$ Pst I/EcoRI fragment with the coding region for ARPP-21, and pTKAlG4.3, which contained the $0.45 \mathrm{~kb}$ Pst I/Kpn I fragment from the 3 ' noncoding region.

Southern blot analysis. Bovine genomic DNA was cleaved with individual restriction endonucleases and electrophoresed on a $1 \%$ agarose gel and transferred to nitrocellulose (Southern, 1975). The filters were hybridized with ${ }^{32} \mathbf{P}$-labeled antisense RNA in a mixture as described 


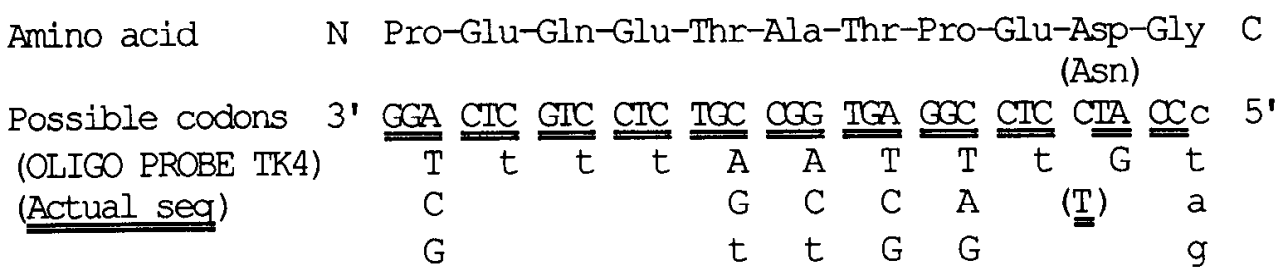

Amino acid $\quad \mathrm{N}$ Leu-Asp-Glu-Glu-Glu-Lys-Leu-Glu-Leu-GIn-Arg C

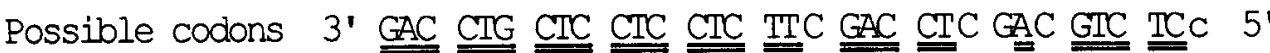

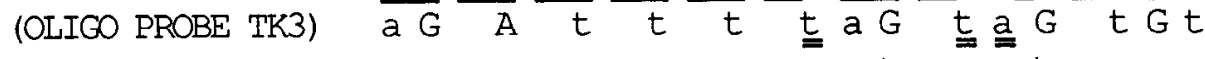
(Actual seq) $t$

a $t$

a

Figure 1. Synthetic oligonucleotide probes used for screening of bovine ARPP-21 clones. The possible sense sequences were deduced from the amino acid sequences (Williams et al., 1989) of purified bovine ARPP-21. Codons in capitals were used as probes. The actual sequence as derived from the cDNA pTKAl is double underlined.

by Kurihara et al. (1988) at $65^{\circ} \mathrm{C}$ with $200 \mu \mathrm{g} / \mathrm{ml}$ yeast tRNA and 100 $\mu \mathrm{g} / \mathrm{ml}$ salmon testis DNA for $20 \mathrm{hr}$. The filters were washed at $65^{\circ} \mathrm{C}$ in $0.1 \%$ SDS, $0.2 \times$ SSC $\left(1 \times\right.$ SSC $=0.15 \mathrm{M} \mathrm{NaCl} ; 0.015 \mathrm{M} \mathrm{Na}_{3}$ citrate $)$ after a wash in $2 \times \mathrm{SSC}$ with $1 \mu \mathrm{g} / \mathrm{ml}$ RNase A at room temperature for $5 \mathrm{~min}$.

Northern blot analysis. Northern blot analysis was performed essentially according to Maniatis et al. (1982) and Thomas (1980). Hybridization procedures were the same as described for Southern blotting, except that the nitrocellulose filters were incubated in a buffer containing $50 \%$ formamide at $55^{\circ} \mathrm{C}$, with $200 \mu \mathrm{g} / \mathrm{ml}$ yeast tRNA and $100 \mu \mathrm{g} / \mathrm{ml}$ salmon testis DNA, and the filters were washed at $65^{\circ} \mathrm{C}$ in $0.1 \%$ SDS, $0.2 \times$ SSC without formamide. A wash in $2 \times$ SSC with $1 \mu \mathrm{g} / \mathrm{ml} \mathrm{RNase}$ A was performed at room temperature prior to the final wash at $60^{\circ} \mathrm{C}$ in $0.1 \%$ SDS, $0.1 \times$ SSC. Calf liver $28 \mathrm{~S}$ rRNA $(4.7 \mathrm{~kb})$ and $18 \mathrm{~S}$ rRNA $(1.9 \mathrm{~kb})$ were used as standards (Pharmacia).

Enzymes and reagents. E. coli DNA polymerase I (Klenow fragment), ribo-, deoxy-, and dideoxy-nucleotide triphosphates, Hind III linker, and a DNA size marker (DRIgest III) were purchased from Pharmacia. RNasin was purchased from Promega. T4 DNA ligase, terminal deoxytransferase, and $E$. coli polynucleotide kinase and restriction endonucleases were purchased from Boehringer Mannheim, Bethesda Research Laboratories, New England Biolabs, or Pharmacia. $\gamma_{-}{ }^{32} \mathrm{P}-\mathrm{rATP}$ $(3000 \mathrm{Ci} / \mathrm{mmol}),\left[\alpha-{ }^{32} \mathrm{P}\right] \mathrm{CTP}(800 \mathrm{Ci} / \mathrm{mmol}),\left[\alpha-{ }^{35} \mathrm{~S}\right] \mathrm{ATP}(500 \mathrm{Ci} / \mathrm{mmol})$ and $\left[\alpha{ }^{-35} \mathrm{P}\right] \mathrm{CTP}(3000 \mathrm{Ci} / \mathrm{mmol})$ were obtained from New England Nuclear. Other chemicals were obtained from standard commercial suppliers.

\section{Results}

Isolation of a cDNA clone for ARPP-21 $\mathrm{mRNA}$

Starting with $0.5 \mu \mathrm{g}$ of poly $(\mathrm{A})^{+}$RNA from bovine caudate nucleus, a cDNA library of $1.0 \times 10^{5}$ clones was constructed using the Okayama-Berg procedure, amplified, and stocked at $-20^{\circ} \mathrm{C}$ (Okayama and Berg, 1982; Kurihara et al., 1988). This library was screened by the colony hybridization method (Grunstein and Hogness, 1975; Maniatis et al., 1982) using a mix of 2 different oligonucleotide probes (oligo TK3 and oligo TK4). These oligonucleotides were designed on the basis of the amino acid sequence of bovine ARPP-21 (Williams et al., 1989) and mammalian codon usage data (Grantham et al., 1981). The amino acid sequences and the corresponding oligonucleotide probes are summarized in Figure 1.

Out of approximately $2.4 \times 10^{5}$ recombinant colonies, 6 colonies gave positive signals and were independently detected with each of the probes. Restriction enzyme analyses and Southern hybridization revealed that the clones were identical except for variations in length at the $5^{\prime}$ end. All further analyses were performed on pTKAl, the longest clone.
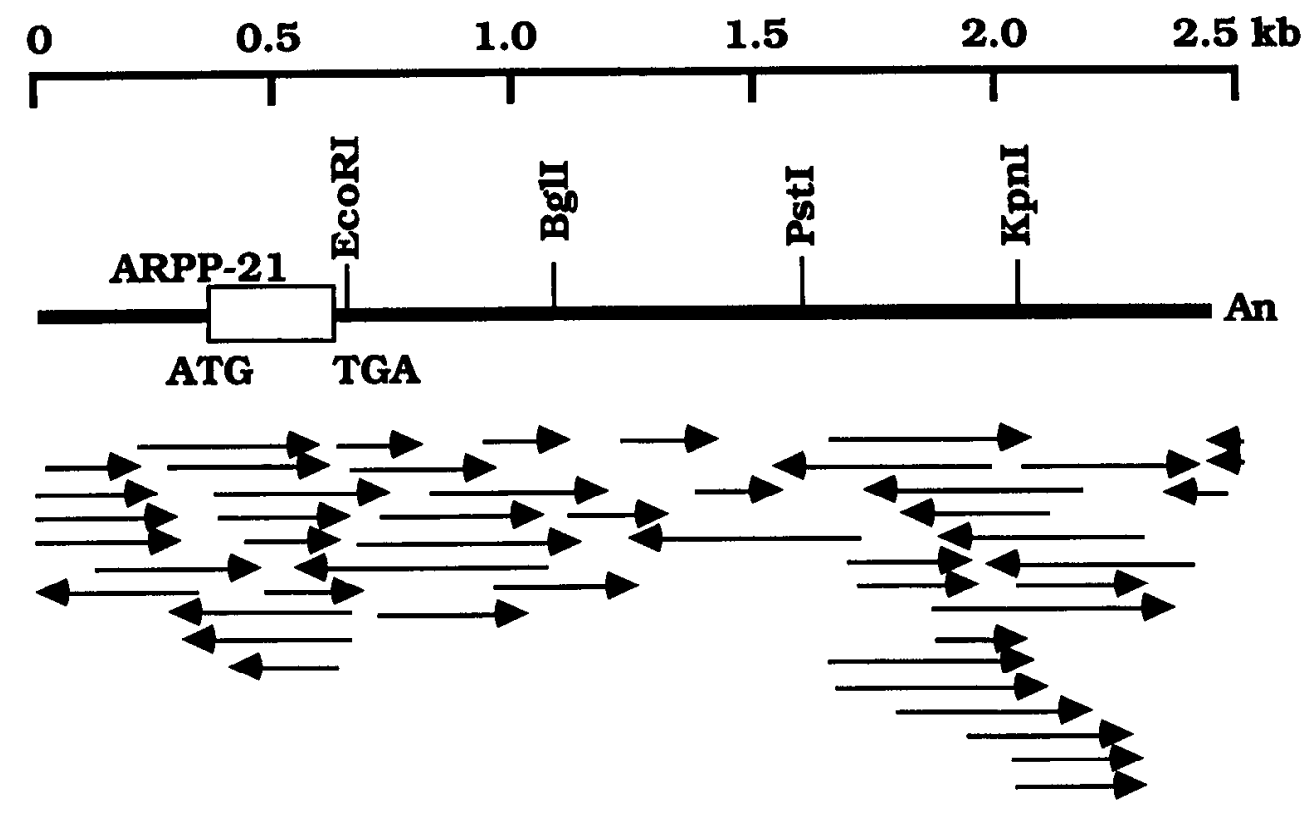

Figure 2. Restriction map and sequencing strategy of pTKAl. The scale above the restriction map indicates the nucleotide positions in kilobases $(\mathrm{kb})$ relative to the first nucleotide. The open box depicts the coding region for the ARPP-21 protein, while the thick black line depicts the untranslated $5^{\prime}$ and $3^{\prime}$ ends. ATG and TGA represent the start and stop codons, respectively. The arrows indicate the sequencing strategy after collecting deletion series of singlestrand subclones (Dale et al., 1985). Overlapping sequences in both directions, not shown in this figure, were derived from bacteriophage Ml3 subclones as templates (Messing, 1983). 


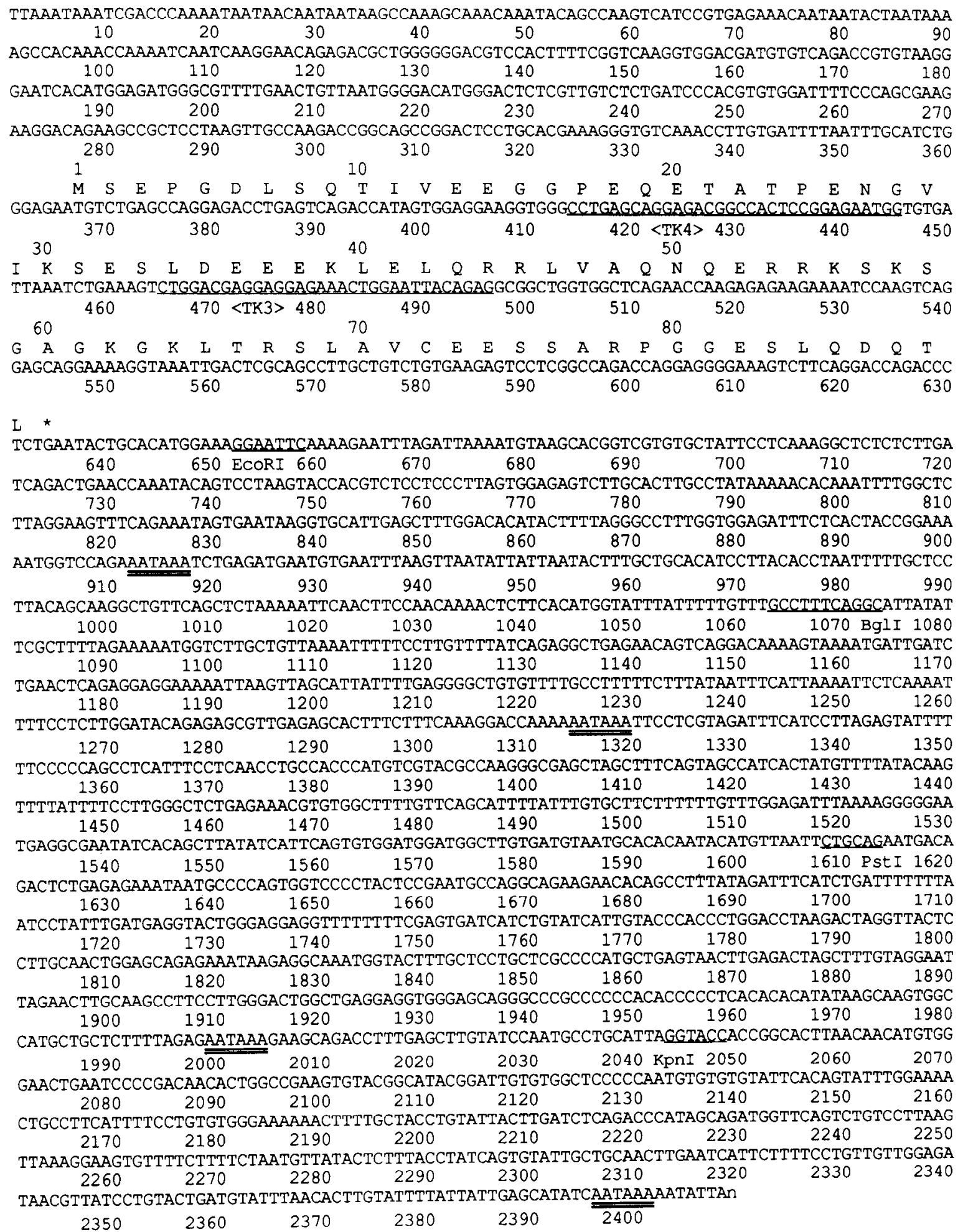

Figure 3. Complete nucleotide sequence of pTKAl and the derived amino acid sequence of bovine ARPP-21. Nucleotide numbering begins at 1 for the first nucleotide after the $\mathrm{G}$ tail in the vector. The areas used to generate the synthetic oligonucleotide probes are underlined and labeled $<\mathrm{Tk} 3>$ and $<\mathrm{Tk} 4>$. Restriction sites are underlined (-), and potential polyadenylation sites are double underlined (

\section{Identification of ARPP-21 cDNA by nucleotide sequencing}

A restriction map analysis and the sequencing strategy for pTKAl are presented in Figure 2. The complete base sequence and deduced amino acid sequence of clone pTKAl are shown in Figure
3. The sequence data indicate that pTKAl is 2407 nucleotides in length, excluding the poly(A) tail. It contains the complete coding sequence corresponding to the bovine ARPP-21 protein, coding for 89 amino acids, including the initiation codon ATG, as well as the termination codon TGA. There are 365 nucleo- 


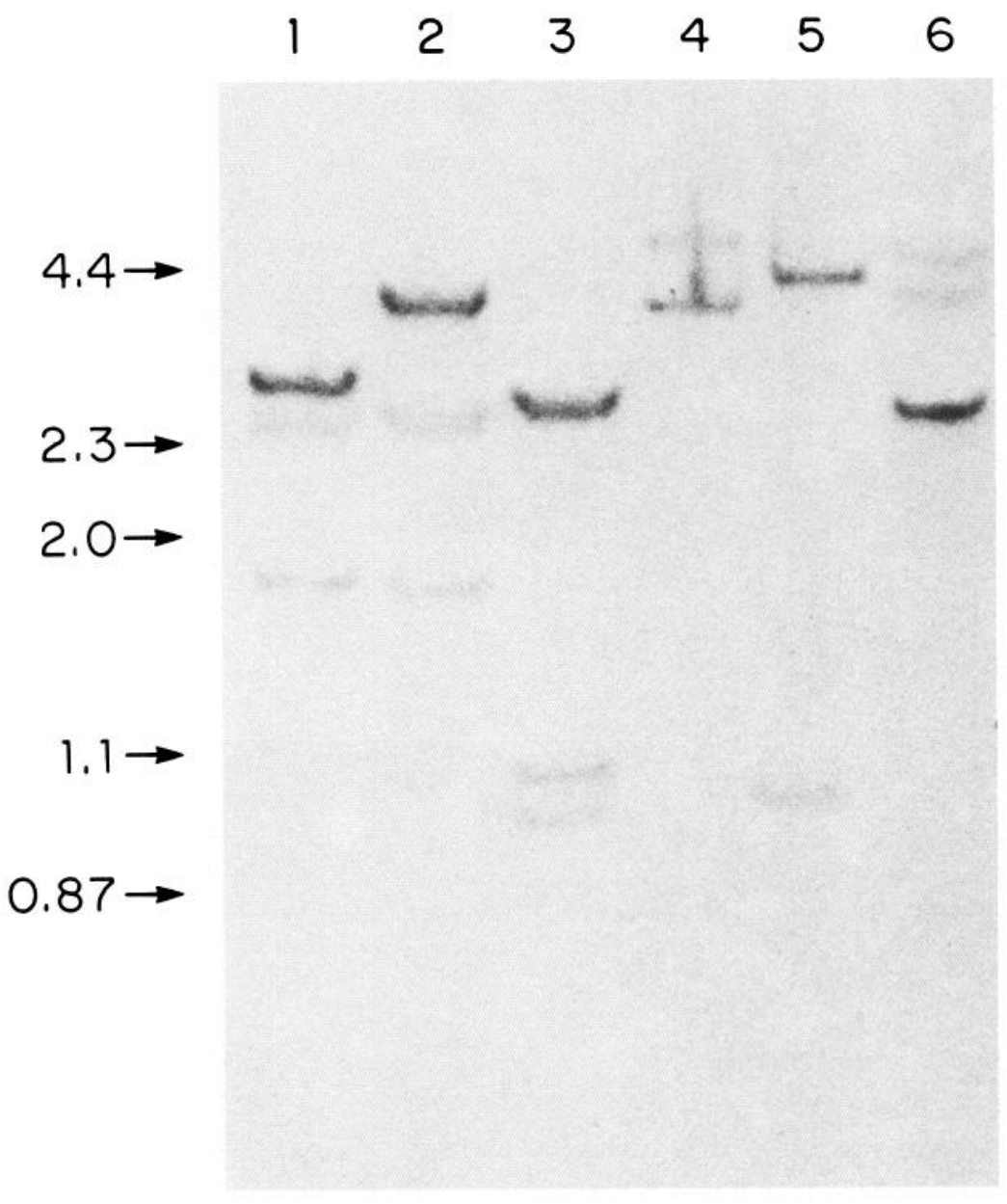

Figure 4. Southern blot analysis of bovine thymus genomic DNA. Twenty micrograms of bovine thymus DNA were digested with restriction endonucleases, electrophoresed through a $1 \%$ agarose gel, transferred to a nitrocellulose filter, and hybridized with ${ }^{32} \mathrm{P}$ labeled pTKAlG4.2, containing the ARPP-21 coding region, but excluding the $3^{\prime}$ untranslated end. Lane 1, Eco $\mathrm{RI}$; lane 2, PST I, lane 3, Eco RI and Pst I; lane 4, Kpn I, lane 5, Bam HI; lane 6, Hind III. Sizes were calculated from coelectrophoresis of DRIgest III (Pharmacia).

tides of $5^{\prime}$ noncoding region and 1775 nucleotides of $3^{\prime}$ noncoding region. There are 4 potential polyadenylation signals, as the consensus sequence AATAAA (Proudfoot and Brownlee, 1976) is present at positions $912,1314,1999$, and 2396. The aspartate at position 25 in the amino acid sequence (Williams et al., 1989) is an asparagine coded by AAT in the DNA sequence. [Amino acid positions are numbered according to the protein sequence in the accompanying paper by Williams et al. (1989), with the first serine being in position 1, as the initiator methionine is not present in the amino acid sequence.] The aspartate may be derived from asparagine by deamidation during the protein purification or peptide-sequencing procedure, or from a second coding sequence. It is unlikely to arise from a second coding sequence as all 6 cDNAs coded for an asparagine with AAT in that position.

\section{Southern blot analysis of bovine genomic DNA}

In order to investigate the genomic organization of ARPP-21, chromosomal DNA from bovine caudate nucleus was analyzed with a probe derived from pTKAlG4.2 (Fig. 4). There were multiple hybridizing bands in all lanes, including those digested with Bam HI and Hind III, for which there are no restriction sites in the cDNA. It appears that either the $0.65 \mathrm{~kb}$ Pst $\mathrm{I} /$ Eco $\mathrm{RI}$ fragment of the cDNA is derived from a minimum of 2 exons, or that there are 2 genes coding for ARPP- 21 mRNA. We attempted to answer this question by performing Southern blot analysis with 2 separate oligomers from nucleotide 1-30 or from 624-654. We found that we could not adequately compare the results of a Southern blot hybridized with a 658 ntd RNA probe to one hybridized with a 30 ntd, end-labeled oligomer (data not shown). The definitive answer requires analysis of the entire gene.

\section{Distribution of ARPP-21 $\mathrm{mRNA}$ in bovine CNS}

The distribution of ARPP-21 mRNA in the bovine CNS was analyzed by Northern blot hybridization with a probe derived from pTKAlG4.2 (Fig. 5). A predominant mRNA species at 2.5 $\mathrm{kb}$ was highly enriched in the caudate nucleus, in agreement with the large amount of protein in this region (Walaas et al., 1983; Hemmings and Greengard, 1989; Ouimet et al., 1989). This mRNA species was also relatively abundant in the cortex, particularly in the occipital and motor areas (Fig. $5 A$ ). The 2.5 $\mathrm{kb}$ band was barely detectable in the hippocampus, cerebellum, or thalamus and was undetectable in the substantia nigra, medullary white matter, and adrenal gland. A minor band at 1.75 $\mathrm{kb}$ could only be detected with pTKAlG4.2 in caudate nucleus poly(A)+RNA (Fig. 5B).

Hybridization with pTKAlG4.2, which contains the coding region for ARPP-21, also yielded a band at $1.0 \mathrm{~kb}$ (Fig. 5). Of note, this was the mRNA species with the greatest amount of hybridization in total cellular RNA from the cerebellum, and also appeared to be present in very small amounts in the substantia nigra. pTKAlG4.3, extending from nucleotide 1613 to 


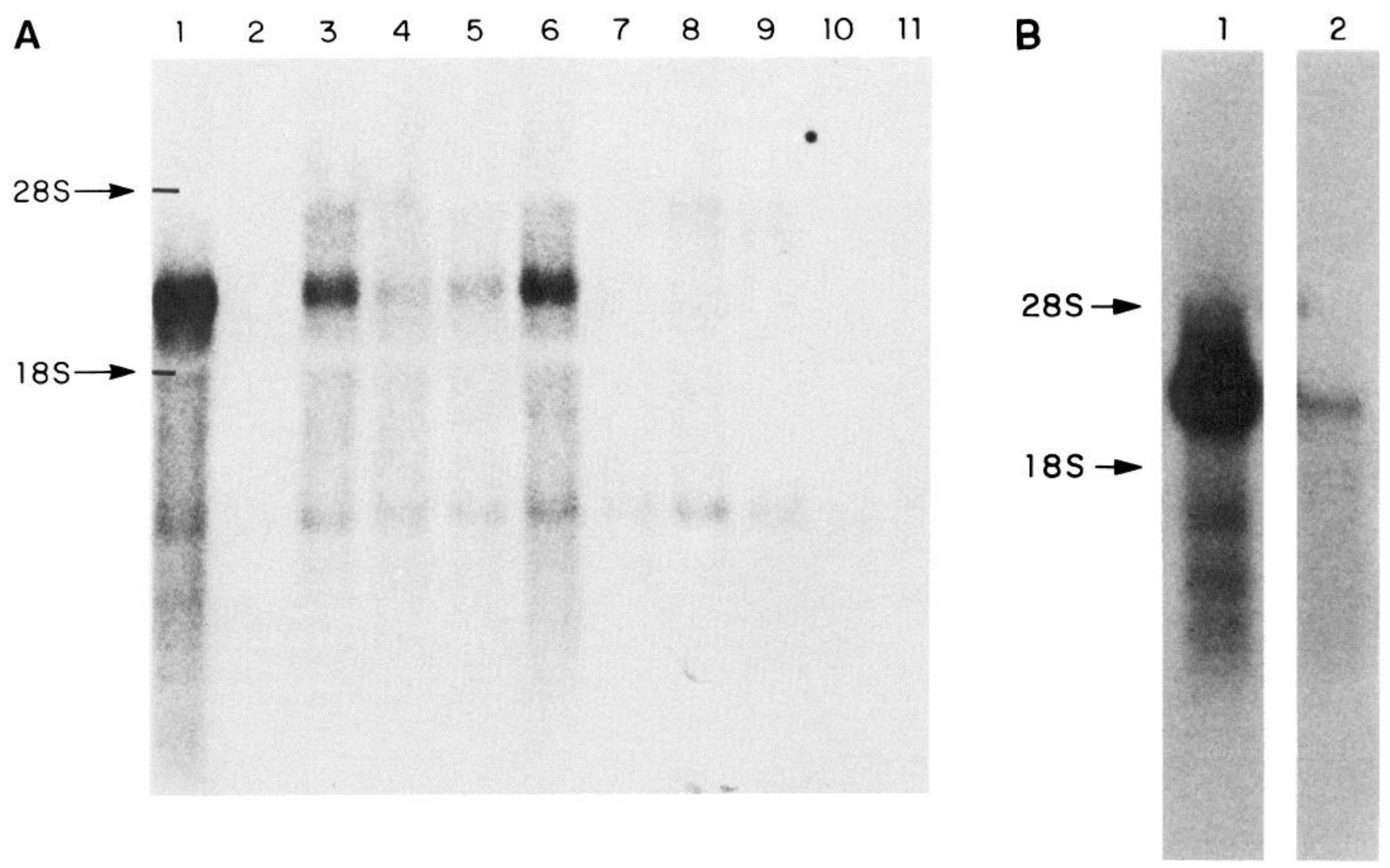

Figure 5. A, Regional distribution of ARPP-21 mRNA in bovine nervous tissue by Northern blot analysis. Twenty micrograms of total RNA were separated by electrophoresis in $1.2 \%$ agarose gel containing $2.2 \mathrm{M}$ formaldehyde and analyzed by Northern blot hybridization with a ${ }^{32} \mathrm{P}$ labeled antisense RNA probe derived from pTKAlG4.2. Lane 1, caudate nucleus; lane 2, substantia nigra; lane 3, occipital cortex; lane 4, prefrontal cortex; lane 5, entorhinal cortex; lane 6, motor cortex; lane 7, hippocampus; lane 8, cerebellum; lane 9, thalamus; lane 10, medullary white matter; lane 11, adrenal gland. $B$, Northern blot analysis was performed as in $A$. Lane 1, $10 \mu \mathrm{g} \mathrm{A}+$ RNA from bovine caudate nucleus; lane 2, $10 \mu \mathrm{g}$ ARNA from bovine caudate nucleus.

2047 , hybridized only to the $2.5 \mathrm{~Kb}$ mRNA species in caudate nucleus RNA and did not hybridize to cerebellar RNA (Fig. 6).

\section{Discussion}

In this paper, we describe the cloning of a cDNA for bovine ARPP-21, a neuron-specific phosphoprotein, which is highly enriched in neurons containing the D-1 dopamine receptor, particularly the medium spiny neurons of the caudate nucleus (Ouimet et al., 1989). Our sequence data (Fig. 3) indicate that the longest clone, pTKAl, has 2407 nucleotides, excluding the poly(A) tail. It codes for a protein of 89 amino acids (267 nucleotides), which corresponds to the bovine ARPP-21 protein except for the presence of the initiator methionine and the substitution of asparagine for aspartate at position 25 . The possible reasons for these discrepancies are discussed above and in the accompanying paper (Williams et al., 1989). The seryl residue, which is phosphorylated by cAMP-dependent protein kinase, is present at position 55. ARPP-21 contains a high percentage of acidic residues (20\%), as does DARPP-32 (Williams et al., 1986; Kurihara et al., 1988), another cAMP-regulated phosphoprotein highly enriched in the medium spiny neurons of the striatum. There is no sequence homology between ARPP- 21 and DARPP32.

Hybridization of bovine caudate poly(A) ${ }^{+}$RNA with a probe that included the coding region for ARPP-21 revealed 3 bands, 2 of which were visible after hybridization with caudate nucleus total cellular RNA. The major band at $2.5 \mathrm{~kb}$ almost certainly represents the mRNA species from which pTKAl was cloned. The minor band at $1.0 \mathrm{~kb}$ can also be clearly detected in total cellular RNA. There are 4 potential polyadenylation signals, as identified by the sequence AATAAA, at positions 912, 1314, 1999 , and 2396 . The fact that only the $2.5 \mathrm{~kb}$ species is detected with a probe derived from the $3^{\prime}$ untranslated region from nucleotide 1608 through 2043 strongly suggests that the 2 RNA species differ in use of alternate polyadenylation sites and in the length of the $3^{\prime}$ untranslated end. We do not yet know the physiologic significance, if any, of region-specific use of alternate polyadenylation sites. Only extremely low levels of ARPP-21 protein can be detected in the cerebellum, and the protein is located only in terminals in the substantia nigra (Ouimet et al., 1989). There is increasing evidence that the untranslated $3^{\prime}$ end of an mRNA species may be important in regulation of mRNA stability and efficiency of translation (Shaw and Kamen, 1986; Strickland et al., 1988), and it is possible that the long $3^{\prime}$ untranslated end present in the $2.5 \mathrm{~kb}$ mRNA species is required for translation. The 2 mRNA species are unlikely to represent the 2 different forms of ARPP-21 protein (see accompanying paper, Williams et al., 1989) as ARPP-21A and ARPP-21B are 


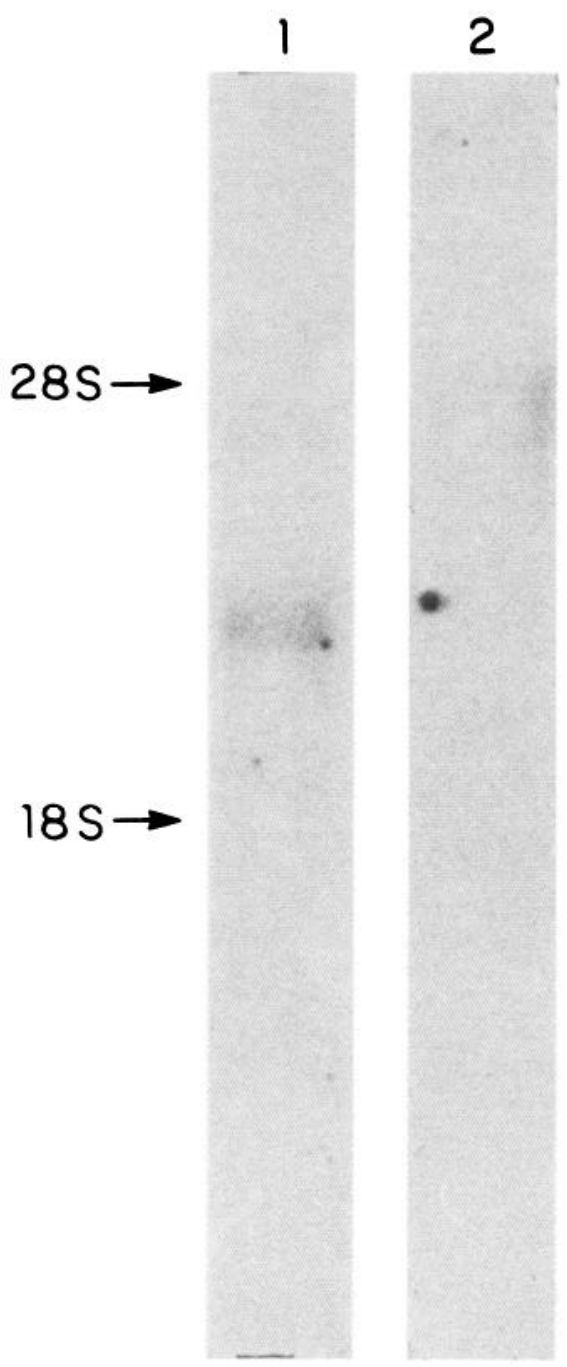

Figure 6. Northern blot analysis of $20 \mu \mathrm{g}$ bovine caudate nucleus (lane 1) and cerebellum (lane 2) total cellular RNA with a ${ }^{32} \mathrm{P}$-labeled antisense RNA probe derived from pTKAlG4.3 (nucleotides 1613-2047). Hybridization and washing conditions were the same as in Figure 5.

present in approximately equal amounts (Hemmings and Greengard, 1989).

Southern blot analysis of bovine thymus genomic DNA revealed that there were multiple restriction fragments that hybridized to ARPP-21 antisense RNA derived from the $5^{\prime}$ end of the clone, including the coding region. Multiple bands were present even when the DNA was digested with enzymes for which there are no sites in the entire ARPP-21 cDNA, including Bam $\mathrm{HI}$ and Hind III. There are 2 possible explanations for this finding. The first is that there are, within this $5^{\prime}$ portion of the gene, intron(s) that have restriction sites for each of the enzymes used in the analysis. The second is that there are 2 genes coding for ARPP-21. These possibilities will be distinguished via study of the structure of the ARPP-21 gene. If there are 2 ARPP-21 genes, the 2 major mRNA species observed may be derived from separate genes.

The regional distribution of ARPP-21 mRNA correlates with that of the protein as detected by immunoprecipitation (Hemmings and Greengard, 1989; J.-A. Girault, unpublished observations) and immunocytochemistry (Ouimet et al., 1989). The greatest concentrations are found in the basal ganglia, particularly in the striatum. Significant, but lower, levels are detected in the cortex, and even lower levels are present in several other brain regions. Like DARPP 32, the highest concentrations of ARPP-21 mRNA and protein are present in areas with the greatest density of D-1 receptors (Boyson et al., 1986), particularly the striatum. The absence of the predominant ARPP-21 mRNA species in the substantia nigra is consistent with the fact that, by immunocytochemistry, ARPP-21 is localized to axons and axon terminals, and not to cell bodies in this region (Ouimet et al., 1989).

In conclusion, we present the structure of a cDNA that encodes a neuron-specific phosphoprotein, ARPP-21. Northern blot analysis shows that the distribution of the mRNA correlates with the localization of ARPP-21-containing cell bodies as detected by immunocytochemistry. In addition, there are 2 major mRNA species, probably arising by differential use of alternate polyadenylation sites. Southern blot analysis suggests that either there are multiple introns within the gene or that there are 2 genes of somewhat different structure. Further analysis of the structure of the ARPP-21 gene and regulation of ARPP-21 mRNA will provide a basis for a detailed investigation of the mechanisms of neuron-specific expression of ARPP-21 within the brain.

\section{References}

Aviv, H., and P. Leder (1972) Purification of biologically active globin messenger RNA by chromatography of oligothymidylic acid-cellulose. Proc. Natl. Acad. Sci. USA 69: 1408-1412.

Boyson, S. J., P. McGonigle, and P. B. Molinoff (1986) Quantitative autoradiographic localization of the $\mathrm{D}_{1}$ and $\mathrm{D}_{2}$ subtypes of dopamine receptors in rat brain. J. Neurosci. 6: 3177-3188.

Chirgwin, J. M., A. E. Przybyla, R. J. MacDonald, and W. J. Rutter (1979) Isolation of biologically active ribonucleic acid from sources enriched in ribonuclease. Biochemistry 18: 5294-5299.

Dale, R. M. K., B. A. McClure, and J. P. Mouchins (1985) A rapid single-stranded cloning strategy for producing a sequential series of overlapping clones for use in DNA sequencing. Application to sequencing the corn mitochondrial 18S rDNA. Plasmid 13: 31-40.

Grantham, R., C. Gautier, M. Gouy, M. Jacobzone, and R. Mercier (1981) Codon catalog usage is a genome strategy modulated for gene expressivity. Nucleic Acids Res. 9: r43-r74.

Grunstein, M. M., and D. S. Hogness (1975) Colony hybridization: A method for the isolation of clone DNAs that contain a specific gene. Proc. Natl. Acad. Sci USA 72: 3961-3965.

Hemmings, H. C., Jr., and Greengard, P. (1989) ARPP-21, a cyclic AMP-regulated phosphoprotein enriched in dopamine-innervated brain regions. I. Purification and characterization of the protein from bovine caudate nucleus. J. Neurosci. 9: 851-864.

Kurihara, T., R. M. Lewis, J. Eisler, and P. Greengard (1988) Cloning of cDNA for DARPP-32, a dopamine- and cyclic AMP-regulated neuronal phosphoprotein. J. Neurosci. 8: 508-517.

Maniatis, T., E. F. Fritsch, and J. Sambrook (1982) Molecular Cloning: A Laboratory Manual, Cold Spring Harbor Laboratory, Cold Spring Harbor, NY.

Melton, D. A., P. A. Krieg, M. R. Rebagliati, T. Maniatis, K. Zinn, and M. R. Green (1984) Efficient in vitro synthesis of biologically active RNA and RNA hybridization probes from plasmids containing a bacteriophage SP6 promoter. Nucleic Acids Res. 12: 7035-7056.

Messing, J. (1983) New M13 vectors for cloning. Methods Enzymol. 101: 20-78.

Nelson, F. K., S. M. Fredman, and G. P. Smith (1981) Filamentous phage DNA cloning vectors: A noninfective mutant with a nonpolar deletion in gene III. Virology 108: 338-350.

Okayama, H., and P. Berg (1982) High-efficiency cloning of full-length cDNA. Mol. Cell. Biol. 2: 161-170.

Ouimet, C. C., H. C. Hemmings, Jr., and P. Greengard (1989) ARPP21 , a cyclic AMP-regulated phosphoprotein enriched in dopamineinnervated brain regions. II. Immunocytochemical localization in rat brain. J. Neurosci. 9: 865-875. 
Proudfoot, N. J., and G. G. Brownlee (1976) $3^{\prime}$ non-coding region sequences in eukaryotic messenger RNA. Nature 263: 211-214.

Sanger, F., S. Nicklen, and A. R. Coulson (1977) DNA sequencing with chain-terminating inhibitors. Proc. Natl. Acad. Sci. USA 74: 5463-5467.

Shaw, G., and R. Kamen (1986) A conserved AU sequence from the 3 ' untranslated region of GM-CSF mRNA mediates selective mRNA degradation. Cell 46: 659-667.

Southern, E. (1975) Detection of specific sequences among DNA fragments separated by gel electrophoresis. J. Mol. Biol. 98: 503-517.

Strickland, S., J. Huarte, D. Belin, A. Vassalli, R. J. Rickles, and J.-D. Vassalli (1988) Antisense RNA directed against the 3 ' noncoding region prevents dormant mRNA activation in mouse oocytes. Science 241: $680-684$.

Thomas, P. S. (1980) Hybridization of denatured RNA and small DNA fragments transferred to nitrocellulose. Proc. Natl. Acad. Sci. USA 77: 5201-5205.

Walaas, S. I., A. C. Nairn, and P. Greengard (1983) Regional distribution of calcium- and cyclic adenosine $3^{\prime}: 5^{\prime}$-monophosphate-regulated protein phosphorylation systems in mammalian brain. II. Soluble systems. J. Neurosci. 3: 291-301.
Williams, K. R., H. C. Hemmings, Jr., M. B. LoPresti, W. H. Konigsberg, and P. Greengard (1986) DARRP-32, a dopamine- and cyclic AMP-regulated neuronal phosphoprotein. Primary structure and homology with protein phosphatase inhibitor-1. J. Biol. Chem. 261: 1890-1903.

Williams, K. R., H. C. Hemmings, Jr., M. B. LoPresti, and P. Greengard (1989) ARPP-21, a cyclic AMP-regulated phosphoprotein enriched in dopamine-innervated brain regions. I. Amino acid sequence of ARPP-21B from bovine caudate nucleus. J. Neurosci. 9: 3631-3637.

Wood, W. B. (1966) Host specificity of DNA produced by Escherichia coli: Bacterial mutations affecting the restriction and modification of DNA. J. Mol. Biol. 16: 118-133.

Yanisch-Perron, C., J. Vieira, and J. Messing (1985) Improved M13 phage cloning vectors and host strains: Nucleotide sequences of the M13mp18 and pUC19 vectors. Gene 33: 103-119.

Zelenka, P., and J. Piatigorsky (1974) Isolation and in vitro translation of d-crystallin mRNA from embryonic lens fibers. Proc. Natl. Acad. Sci. USA 71: 1896-1900. 